DOI: 10.18276/SIP.2018.52/2-43

\title{
Joanna Ziomek*
}

Politechnika Poznańska

\section{THE IMPORTANCE OF CREATIVITY AS THE CORE COMPETENCE OF EMPLOYEES IN THE SELECTED ENTERPRISES IN POLAND}

\begin{abstract}
The article includes issues related to creativity of human resources. Problems of creativity are still not widely studied and described in Polish literature. The aim of this article is to review the role and importance of creativity of employees in chosen enterprises in Poland. The article has a theoretical and empirical character. Theoretical part of the article focuses on the description of the concepts related to creativity - one of the key competences of employees. The empirical part of the article presents the results and conclusions from interviews that were conducted with representatives of selected enterprises located in Poland. The results of the conducted research confirm that creativity is one of the key competences of employees and employers try to create appropriate conditions conducive to the development of creativity.
\end{abstract}

Keywords: creativity, innovations, enterprise

JEL codes: O30, O31

* e-mail address: joanna.ziomek@put.poznan.pl. 


\section{Introduction}

Ensuring or maintaining a long-term competitive advantage becomes more and more difficult because of globalization, changing environment and the need to constantly compete with other entities. Strengthening the position of business entities is possible mainly due to the focus on the originality and uniqueness of created solutions concerning product, process, marketing or organization. The creative staff is one of the most important resources initiating and bringing about the mentioned effects. Therefore, the key task of the company's managers is to choose the right people for each job position, as well as to provide them with opportunities and conditions for creative use of their potential. The aim of the study is to verify the approach of selected enterprises operating in Poland to issues related to the creativity of their employees. This research is quite important, because creativity is nowadays one of the key competences of employees in the enterprises all over the world that leads to innovation.

\section{Creativity as the core competence of employees in an enterprise}

Competing companies are now striving to improve or develop solutions that are unique, but at the same time do not generate high costs. The implementation of these activities will not be effective without the involvement of creative people working in a suitable environment that is conducive to creative activity. Thanks to such people, it is possible to search, adapt, implement and disseminate new solutions that bring individual and social benefits (Bal-Woźniak, 2010, p. 258). However, employees should have the appropriate competences.

The competences can be interpreted as the scope of knowledge, skills and responsibility (Rogozińska-Pawelczyk, 2006, p. 101). Having appropriate competences entitles a given person to carrying out activities, issuing opinions and making decisions. One of the most important features of competence is that it can be updated by performing specific activities. Therefore, it is able to evolve along with changes occurring in the economy and human life (Kwiatkowski, Symela, 2001, p. 22). Considering the above features, it can be concluded that one of the key competences of employees is creativity. 
The word "creativity" is nowadays used to describe many objects, people, fields or phenomena. Already more than half a century ago, Morris I. Stein (1953, p. 312) pointed out that creativity is process that results in a novel product that is accepted by a significant group of others as useful, tenable or satisfying at some point in time. According to Teresa Amabile, who conducted a lot of research in the field of creativity, creativity is a set of several components, such as knowledge, motivation, competence, creative thinking skills and organizational culture (Amabile, 1996, pp. 77-78). Krzysztof J. Szmidt (2013, p. 22) emphasizes that creativity is the human ability to create new and valuable products. Creativity can also be treated as a human skill that allows "other perception of the world, creating new ideas, expressing knowledge and differentness" (Szara, 2014, p. 201). Edward de Bono (2007, p. 12), one of the leading authorities in the field of creative thinking, believes that "creativity is a skill that anyone can learn, practice and use". The basis for the creative and effective operation of enterprises seems to be an appropriate organizational culture, which is a collection of common values, goals and beliefs of the company that shape the engagement and the manner and quality of work of all the people employed in it (Armstrong, 1997, p. 115).

Creativity is considered to be the first step of the innovation process, as the source of generating new ideas. The possibilities of these ideas can be verified with basic research. Creativity is especially useful when new ideas are transferred into solutions that improve the functioning of a business (e.g. a new product or a process). Therefore creativity should be considered in a practical terms, not only in concept terms. This concept should be in the centre of interest of all enterprises, not only those with a high level of innovation.

Creative thinking is very often treated as a personality human disposition (Kaliszczak, 2013, p. 78). It distinguishes: unconventional approach to various problems, unusual ideas for solving them, as well as positive attitude, learning from mistakes and determination to create innovative solutions. Economists often indicate that creativity is the only inexhaustible resource that provides a competitive advantage (Jung, 2010, p. 222). Therefore, it can be assumed that the greatest benefits are, for enterprises, to invest in the human factor.

Summing up, it can be stated that the creativity of employees is activated primarily when the company has a positive atmosphere, allowing unconventional thinking and undertaking creative activities. Therefore, it is necessary to create the 
right conditions in the enterprise, thanks to which every employee will be able to see current problems and will try to solve them in a creative way. Thanks to the appropriate organizational culture, it will be possible to develop new solutions that will lead to an increase in the level of innovation.

\section{Characteristics of the research sample and the interview questionnaire}

There were 8 people taking part in the research, four men and four women. They were Polish entrepreneurs, business owners, managers. In all eight cases, the companies were established more than 10 years ago. Five of them are manufacturing, trade and service companies, and the remaining three belong to the service sector. Each company employs more than 20 employees, including two companies employing more than 200 and one company more than 2000 employees. These enterprises are innovative and they introduce innovative products to the market. Some of these companies have their own patents of machines and devices or solutions.

Taking into consideration the request of the surveyed entities, only the outline of enterprises will be presented, without providing exact names. One company is an agricultural holding and an agricultural processing enterprise. It also educates farmers about the need for fertilizing crops. It has a system (meteorological station) that informs farmers from around about potential crop risks, and also sells fertilizers and spraying chemicals. The production and packaging line is $90 \%$ designed and created by the company's employees. The company has also its patents. The company has created the largest innovative plantation of one fruit in Europe. The enterprise uses organic wastes to create new products, based on the TRIZ principle (Theory of Reszenija Izobretatielskich Zadacz) - processing damage to an opportunity.

The second company operates in the industrial sector, offering specialized solutions for, among others, departments of the energy, metallurgical, aerospace and military industries. Manufactures and trades in technical chemistry, adhesives, lubricants. Its products annually win contests for the best maintenance products.

The third company operates in the medical sector. It manufactures and trades chemical products. It also educates medical facilities in the field of cleaning and disinfection. It actively participates in many conferences in Poland and abroad. The company constantly introduces innovative products to the market. 
The fourth company is a grain and milling enterprise producing flour of various types and ready-made baking mixes and trading grains. It has its own laboratories equipped with the latest generation of measuring devices. Recently, as the only company in Poland, it has created the grinding technology of another product.

The fifth company is a leader in the five-star hotel market, offering innovative services tailored to both individual and institutional clients. It introduces constant changes concerning customer service. It results in really high satisfaction of customers - over $90 \%$ of guests would recommend this hotel to other people.

The sixth company belongs to an international corporation - 40 countries and approximately 70,000 employees. The company designs and implements individual solutions tailored to clients in the areas of digital marketing, financial services, supply chain management and IT services, as well as customer relationship management.

The last two companies are fitness clubs with an area of less than $1000 \mathrm{~m}^{2}$. They introduce new services to clients, develop and win prizes in various competitions (including a club with passion).

The interview questionnaire was used in the research. The owners and managers of the surveyed companies answered questions based on the following problem: What is the approach of the researched enterprises to issues related to the creativity of their employees?

Some open, specific questions of the in-depth interview were prepared to answer this question:

1. Which aspect of employees' competencies is the most important to the company?

2. What unique competencies does the ideal employee have?

3. Is the creativity of the employees a necessary competence to work in your company?

4. How is the level of creativity of employees or potential employees verified?

5. What are the most important criteria for hiring creative employees?

6. Are there conditions that stimulate creativity and creative thinking in the company?

7. Give examples of solutions that encourage creativity and creative thinking in the enterprise.

8. Do employees have the opportunity to submit and implement their own ideas? If so, what do you usually think of such ideas? 
9. What are the most important factors that limit creative thinking in the enterprise?

10. Do you think the creativity of your employees determines the level of innovation of the company?

\section{Research results}

All respondents think that knowledge, skills, responsibility and attitude are of the great importance. Most companies claimed that skills are very important for the company, but on the other hand attitude seemed to be as important as skills. The owner of one company focuses the most on attitude. He thinks that the employee can learn in the company to get both knowledge and skills, but it is not possible to change his or her attitude. Only in corporations skills and knowledge seems to be more important than attitude. What is more, employers can see the difference between soft skills and hard skills. Some of them think that soft skills are really important, especially from the service sector. Four employers state that it is more difficult to teach soft skills than hard ones.

Talking about unique competencies that the ideal employee has, respondents emphasize the role of communication, critical thinking, problem solving, creativity, enthusiasm, self-motivation, attitude, teamwork. Some managers pointed responsibility, commitment or consistency as unique competencies.

Out of these unique competencies, creativity is a key competency, but it depends mainly on position level. Not for all employees in the company creativity is the most important competency. In one corporation, the manager found that some operational positions require other competences than creativity. However, some of the positions require creativity from an employee, for example: the marketing department, sales department, PR, product creation department or the department dealing with the creation of advertising content. Executive Chef, sales or marketing director must be creative in a hotel business. And in their case it is a key competence. But creativity is not necessary for employees at lower levels. Especially when these are executive positions that require action in accordance with corporate procedures and standards. In the industrial enterprise, the manager stated that creativity is not indispensable, but it helps a lot in running a business and developing a company or improving quality. One researched person recognized that creativity is always necessary to do the job. 
During recruitment for positions that require creativity, a case study with specific tasks or an assessment centre are conducted in a hotel business. In the company that searches for solutions for clients, each manager, during the employee assessment, has an empowerment/leadership ratio measured. This is a parameter that shows the use of the creative potential of employees. Over half of the surveyed companies use conversation, drawing conclusions and planning activities as verification of already employed employees. For potential employees, there is also a conversation during which tasks and challenges are set. The way the candidate deals with them is observed. Employees also brainstorm to assess the creativity of future employees.

New ideas, better quality of products and services, growth of the company, value creation and the competitive advantage are pointed as the most important criteria for hiring creative employees.

When asking about the creative climate and conditions that stimulate creativity and creative thinking in the company, 7 out of 8 of the respondents said that such a climate occurs in their companies. Only one manager stated that he usually did not see such a climate, and one person recognized that it depended on the organizational culture in the company and its level of development. In another company (corporation), there was little space for creativity (American organizational culture). This was due to the fact that the procedure and standards were ready for each operational activity.

In a company with a high social responsibility, a climate for creativity is created through daily conversations and meetings with the owner. Other respondents mention also brainstorming, workshops or group work. Most of the researched companies give employees interesting and ambitious tasks, and some companies provide freedom of action. In one enterprise, one point of the code is applied - daily reading: "I'm a committed and fully responsible entrepreneur" and "I'm looking for a way, not a reason. I focus on the solution, not the problem, I'm not looking for excuses."

In the company that belongs to an international group, there are ambassadors who are supposed to promote creativity. Research areas are created in which new products and innovative solutions are created. Additionally, the company organizes periodic competitions for the most innovative projects. These projects are rewarded and the best ideas are implemented in the entire corporation around the world. 
Only one of the respondents stated that the majority of managers in the company suppresses the creativity of employees due to fear of change. In some cases, excess of work causes a lack of time for creative activities. Unfortunately some employees who have more free time, do not feel motivated to be creative.

Employees, in majority of the researched companies, can create their own ideas. When these ideas are good, according to the managers, they are implemented to the company. The ideas vary from the position in the companies. Concerning managers, they usually create big projects for the whole company or some departments. But also some operational employees can come up with creative solutions of daily problems. In majority of researched companies, good and creative ideas are implemented in the company's life and it does not matter if they were submitted by employees of higher or lower positions.

In one hotel industry company there are special programs - Idea Box. It is placed in the employee canteen and every employee can submit his or her ideas, rationalization projects, facilitations, interesting initiatives. The best ideas are implemented and rewarded. In an agricultural holding, the manager believes that the ideas of all employees (higher and lower positions) should be taken into account, because they are able to improve the processes they are best familiar to. According to him, it may be difficult for an outsider to know the whole process completely. In this company and in an industrial enterprise, good ideas are implemented relatively quickly, and employees immediately receive financial gratification and are appreciated by the company's management. In some companies, various competitions are organized in which employees can submit their ideas. Only in one surveyed enterprise, the management sporadically uses the ideas of others. It is due to the fact that managers think that only their ideas are appropriate. The employees are taught that their ideas are rejected and as a consequence, they rarely decide to be creative and create new ideas.

The most important factors that limit creative thinking in the enterprise are unwillingness of managers towards creative ideas of employees, but also procedures and standards for each operational activity, excessive control, excess of duties, time pressure, or lack of managerial involvement in promoting attitudes that develop creativity. Lack of trust is perceived as a huge limitation too, as well as fear of change or fear of assessment. 
Concerning creativity influence on the level of innovation of the company, every researched person claimed that this influence was huge. Managers could see that correlation, but in some companies the employees' competencies were not fully used. In one case, the researched person blames the company's general director and the HR department. In the majority of surveyed enterprises, managers try to use the potential of their creative employees to increase the company's innovation level.

\section{Conclusions}

Due to a small research sample, the obtained research results should not be generalized broadly. However, the importance of employees creativity for the researched entrepreneurs should be emphasized. The vast majority of the surveyed innovative enterprises appreciate their creative employees, realizing that they can bring profits to the company and help the company to achieve a competitive advantage. This contributes to making a creative climate that helps coming up with creative thinking and creating innovations. Employees are motivated to thinking and acting in a creative way. The financial gratification is just one of many motivating factors. However, companies are trying to simultaneously eliminate all barriers that inhibit creativity in the workplace.

\section{Bibliography}

Amabile, T. (1998). How to kill creativity. Harvard Business Review, 5 (76), 76-87.

Armstrong, M. (1997). Jak być lepszym menedżerem. Warszawa: Dom Wydawniczy ABC.

Bal-Woźniak, T. (2010). Warunki usprawnienia zarządzania innowacyjnościa w kontekście wspótczesnych wyzwań. In: S. Lachiewicz, A. Zakrzewska-Bielawska (eds.), Zarządzanie wiedza i innowacjami we wspótczesnych organizacjach (pp. 257-273). Łódź: Wydawnictwo Politechniki Łódzkiej.

de Bono, E. (2007). Umyst kreatywny. Warszawa: Wydawnictwo Studio Emka.

Jung, B. (2010). Kreatywne gospodarki i ,kreatywna klasa”. Otoczenie mediów ery Web 2.0. In: B. Jung (ed.), Wokót mediów ery Web 2.0 (pp. 222-241). Warszawa: Wydawnictwa Akademickie i Profesjonalne.

Kaliszczak, L. (2013). Kreatywność i innowacyjność w kształtowaniu wartości rynkowej oraz przewagi konkurencyjnej przedsiębiorstw. Przedsiębiorstwo i Region, 5, 77-87.

Kwiatkowski, M., Symela, K. (2001). Standardy kwalifikacji zawodowych. Teoria, metodologia, projekty. Warszawa: Instytut Badań Edukacyjnych. 
Rogozińska-Pawełczyk, A. (2006). Kompetencje w organizacji. Acta Universitatis Lodziendzis, Folia Oeconomica, 199, 99-120.

Stein, M.I. (1953). Creativity and culture. The Journal of Psychology, 36, 311-322.

Szara, K. (2014). Kreatywność a innowacyjność w działalności podkarpackich przedsiębiorców. Zeszyty Naukowe MWSE w Tarnowie, 1 (24), 201-210.

Szmidt, K.J. (2013). Trening kreatywności. Gliwice: Wydawnictwo HELION.

\section{ZNACZENIE KREATYWNOŚCI JAKO PODSTAWOWEJ KOMPETENCJI PRACOWNIKÓW W WYBRANYCH PRZEDSIĘBIORSTWACH W POLSCE}

\section{Streszczenie}

W artykule uwzględniono zagadnienia związane z kreatywnością zasobów ludzkich. Problemy dotyczące kreatywności wciąż nie są szeroko badane i opisywane w polskiej literaturze. Celem artykułu jest zweryfikowanie roli i znaczenia kreatywności pracowników zatrudnionych w wybranych przedsiębiorstwach w Polsce. Artykuł ma charakter teoretyczny i empiryczny. W części teoretycznej artykułu skupiono się na opisie pojęć związanych z kreatywnością, czyli jednej z kluczowych kompetencji pracowników. W części badawczej artykułu zaprezentowano wyniki badań oraz wnioski z wywiadów, które przeprowadzono z przedstawicielami wybranych przedsiębiorstw zlokalizowanych w Polsce. Wyniki przeprowadzonych badań potwierdzają, że kreatywność jest jedną z kluczowych kompetencji pracowników, a pracodawcy starają się stworzyć w przedsiębiorstwie odpowiednie warunki sprzyjające rozwojowi kreatywności.

Słowa kluczowe: kreatywność, innowacje, przedsiębiorstwo

Kody JEL: O30, O31 